\title{
From Illegal, Unreported and Unregulated Fishing to Transnational Organised Crime in Fishery from an Indonesian Perspective*
}

\author{
Aryuni Yuliantiningsih ${ }^{* *} \&$ Hartiwiningsih ${ }^{* * *} \&$ \\ Ade Maman Suherman ${ }^{* * * *} \&$ Emmy Latifah ${ }^{* * * * *}$
}

Illegal, unreported and unregulated fishing (IUUF) is a complex problem because IUUF perpetrators not only have fisheries management issues, but also commit other crimes. This phenomenon raises further academic analysis of crime in fisheries at domestic and international levels. Indonesia has experienced different events leading to addressing crimes related to fisheries, which initially came from IUUF practices. To achieve legal certainty, crimes in fisheries issues must be separated from IUUF because IUUF is a matter under the mandate of FAO and crime in fishery is under the mandate of UNODC. Many have mixed IUUF and crimes in fishery in one basket, making the matter confusing from legal and practical point of view. At the domestic level, there must be a regulatory framework recognizing the linkage between fisheries and criminal activities At the international level, meanwhile, there must be an international

* The research and publication was supported by the Doctoral Dissertation Research Grant of Ministry of Research and Technology of Higher Education Indonesia. (Contract Number: 059/SP2H/LT/DPRM/2018). The authors would like to thank Ambassador Arif Havas Oegroseno for his valuable comments on the earlier version of this paper.

** Doctoral Candidate at Faculty of Law of Sebelas Maret University (UNS), Surakarta, Indonesia; Lecturer at Faculty of Law Jenderal Soedirman University (UNSOED, Purwokerto). S.H. (UNSOED), M.H. (Padjajaran Univ./UNPAD, Bandung). ORCID: https://orcid.org/0000-0002-0761-5345. The author may be contacted at: aryuni71@gmail.com / Address: Law Faculty, UNSOED, Jl. H.R. Bunyamin 708, Puwokerto, Indonesia.

*** Professor in criminal law at UNS. S.H (Lampung Univ.), M. Hum./Ph.D. (UNDIP). ORCID: https://orcid.org/00000003-3761-9117 The author may be contacted at: hartiwiningsih@yahoo.com/Address: Jl.Ir. Sutami 36 A Central Java, Indonesia.

**** Professor in international law at UNSOED. S.H. (UNSOED), MSc.(Groningen), Ph.D. (Univ. of Indonesia, Jakarta). ORCID: https://orcid.org/0000-0001-6888-8972. The author may be contacted at: ademamans@yahoo.com / Address: Jl. HR Bunyamin, 708 Kampus UNSOED Grendeng Purwokerto, Central Java, Indonesia.

***** Associate Professor at UNS. S.H (UNS), M.H./Ph.D. (UNPAD). ORCID: https://orcid.org./0000-0001-9593-1163. The author may be contacted at: emmy.latifah@yahoo.com /Address: Jl. Ir. Sutami 36 A, Central Java, Solo, Indonesia. DOI: http://dx.doi.org/10.14330/jeail.2018.11.2.04 
cooperation through existing frameworks such as Mutual Legal Assistance.

\section{Keywords}

IUUF, Crime in Fishery Sector, TOC, Indonesia

\section{Introduction}

Illegal, Unreported and Unregulated Fishing ("IUUF") is a global issue. It has decreased the world fish stock more than 15 percent causing the global loss of up to 26 million tons of fish annually. ${ }^{1}$ The concept of IUUF was set under the International Plan of Action to Prevent, Deter and Eliminate Illegal, Unreported and Unregulated Fishing ${ }^{2}$ ("IPOA-IUU") in 2001, which was initiated by the Food and Agriculture Organisation ("FAO") in the context of implementing the Code of Conduct for Responsible Fisheries (“CCRF”). The IPOA-IUU defines IUUF as:

activities in the areas under the jurisdiction of a state regulation without the permission of that state, or in contravention of its law and regulation, fishing in waters managed by regional fisheries management organisations (RFMOs) in contravention of conservation and management adopted by that RFMO by vessels flying the flag of members and cooperating non-members, non-members, vessels without nationality, and fishing entities; mis-reporting, under-reporting and nonreporting of catch in national waters and in RFMO areas; and fishing in areas where and for fisheries in which there are no applicable regulations. ${ }^{3}$

These examples are mainly fisheries management and compliance concerns. Ostensibly, they do not involve criminal acts. Paragraph 3.4 of the IPOA also states: “... certain unregulated fishing may take place in a manner which is not in violation of applicable international law, and may not require the application of measures envisaged under the International Plan of Action. This provision suggest that not all unregulated fishing activities are illegal, particularly fishing activities where no

1 FAO, The State of World Fisheries and Aquaculture 6 (2016), available at http://www.fao.org/3/a-i5798e.pdf (last visited on Oct. 17, 2018).

2 FAO, International Plan of Action - IUU (2001), available at http://www.fao.org/3/y3536e04.htm (last visited on Oct. 2, 2018).

3 IPOA-IUU, 93. 
management measure are in place."4 Most countries regulate IUUF as a problem of fisheries management.

In practice, the perpetrators of IUUF also commit criminal acts and transnational organised crimes ("TOC"). In 2011, the United Nations Office on Drugs and Crime ("UNODC") released a report on Transnational Organised Crime in Fishing Industry. The TOC in the fishing industry includes human trafficking, people smuggling, illicit drugs, corruption and piracy. ${ }^{6}$ The cases has occurred in several countries, including Indonesia.

In 2015, the Associated Press (“AP”) reported the brutal conditions of migrant workers in Thai fishing vessels. More than 2,000 slaves, mostly Burmese who worked for Thai vessels, have been rescued and freed from Benjina, Indonesia. ${ }^{7}$ The migrants violated human rights in the fishing industry such as child labour, human trafficking, substandard living conditions and physical and mental tortures. ${ }^{8}$ These cases show that IUUF is not only a problem of fish theft, but often related to other crimes, which are not the concern of FAO.

Then, Susi Pudjiastuti, the Minister of Maritime Affairs and Fisheries ("MMAF"), addressed several policies to prevent and combat IUUF, such as issuing moratorium policy for ex-foreign vessels. The moratorium was followed by an analysis and evaluation ("Anev") of the ex-foreign vessels between March and October 2015. Based on the document analysis and field inspections conducted in 17 regions on 1,132 vessels, it was found that all the companies and vessels violated fisheries regulation such as forgery of vessel licensing documents, narcotics and human trafficking and money laundering. ${ }^{9}$

In 2015, Susi Pudjiastuti asked the international community to recognise the practice IUUF as a form of TOC. ${ }^{10}$ Therefore, at the 25th session of Commission on

4 M. Robles, Tightening the Net: The Legal Link between Illegal, Unreported and Unregulated Fishing and Transnational Crime under International, 29 OCEAN Y.B. 144-65 (2015).

5 UNODC, Transnational Organized Crime in Fishing Industry (2011), at. 4, available at http://www.unodc.org/ documents/human-trafficking/Issue_Paper_-_TOC_in_the_Fishing_Industry.pdf(last visited on Aug. 23, 2018).

$6 \quad I d$.

7 See Seafood from Slaves: An AP investigation helps free slaves in the 21st century, available at http://www.ap.org/ explore/seafood-from-slaves (last visited on Oct. 4, 2018). See also Z. Mutaqin, Modern-day Slavery at Sea: Human Trafficking in the Thai Fishing Industry, 11 J. EAST AsIA \& INT'L L. 76-97 (2018).

8 See generally IOM, Report on Human Trafficking, Forced Labour and Fisheries Crime in the Indonesian Fishing InDUSTRY (2016), available at https://www.iom.int/sites/default/files/country/docs/indonesia/Human-TraffickingForced-Labour-and-Fisheries-Crime-in-the-Indonesian-Fishing-Industry-IOM.pdf (last visited on Aug. 23, 2018).

9 Y. Husein, Strategy on Combating IUU Fishing and Post Moratorium Policies Plan, available at http://www.fishcrime. info/assets/Uploads/Yunus-Husein-Indonesian-Approach-To-Tackling-Fisheries-Crime.pdf (last visited on Aug. 20, 2018).

10 T. Salim, Indonesia Wants IUU fishing to be Treated as Transnational Organised Crime, Asia News, Nov. 16, 2015, 
Crime Prevention and Criminal Justice (“CCPCJ") on May 23-26, 2016, the Indonesian government began to emphasise the mainstream concept of Transnational Organised Fisheries Crime ("TOFC") to get recognition by the United Nations General Assembly ("UNGA"). ${ }^{11}$ To date, however, the UNGA has not recognised the concept of TOFC because international law has not set the term 'fisheries crime.' Hence, it is necessary to examine the legal concept that is sufficient to face the phenomenon of a linkage between IUU fishing and related crimes.

There are several publications that examine the linkages between IUU fishing and TOC. In her paper titled, Laundering Fish in the Global Undercurrents: Illegal, Unreported, and Unregulated Fishing and Transnational Organised Crime, Anastasia Telestky stated that IUU fishing on a large scale could be categorised as TOC. ${ }^{12}$ Besides, Mary Ann Palma-Robles identified the concept of 'fisheries crime' in the context of transnational and environmental crime in her article titled, Tightening the Net: The Legal Link between Illegal, Unreported and Unregulated Fishing and Transnational Crime under International Law. ${ }^{13}$ Furthermore, Teale Bandaroff explains that the IUU fishing methods have TOC character at all stages of a fisheries value chain. ${ }^{14}$ Last, Ionne Chapsos hypothesises that illegal fishing and the emergence of 'fisheries crime' in Indonesia can be categorised as TOC. ${ }^{15}$

Many experts and the Indonesian government have not considered the appropriate legal terminology to address IUUF and TOC in fisheries. Most of them still mix both concepts and consider 'fisheries crime' as a new type of crime. The Indonesian government addressed: “Ambassador of the Republic of Indonesia’s Permanent Representative at the United Nations, Rachmat Budiman specifically emphasized that fisheries crime is a new type of transnational organized crime, which is a problem

available at $\mathrm{http}: / /$ annx.asianews.network/content/indonesia-wants-iuu-fishing-be-treated-transnational-organisedcrime-3820 (last visited on Aug. 25, 2018).

11 P. Widakuswara, Indonesia Urgues UN to Declare Fish Theft a Transnational Crime, VOA News, June 10, 2017, available at https://www.voanews.com/a/indonesia-urges-united-nations-declare-fish-theft-transnationalcrime/3895243.html (last visited on Oct. 20, 2018).

12 A. Telestky, Laundering Fish in the Global Undercurrents: Illegal, Unreported, and Unregulated Fishing and Transnational Organized Crime, 41 Ecology L.Q. 943 (2015), available at file://C:/Users/user/AppData/ Local/Microsoft/Windows/INetCache/IE/3LCSH9VO/Laundering \%20Fish\%20in\%20the\%20Global\%20 Undercurrents_\%20Illegal\%20Unreported.pdf(last visited on Oct. 25, 2018).

13 M. Palma-Robles, Tightening the Net: The Legal Link between Illegal, Unreported and Unregulated Fishing and Transnational Crime under International Law, 29 OCEAN Y.B. 149 (2015).

14 T. Bandaroff, The Illegal Fishing And Organized Crime Nexus: Illegal Fishing As Transnational Organized Crime, Global Initiative And Black Fish 26 (2015).

15 I. Chapsos \& S. Hamilton, Illegal, Fishing and Fisheries Crime as a Transnational Organized Crime in Indonesia (2018). 
and a threat to many countries." ${ }^{, 16}$ In fact, IUUF is fundamentally different from the crimes in the fisheries sectors, because these two different issues require different approaches. IUUF requires correct management approaches in accordance with the FAO guidance. Meanwhile, crimes in fisheries, especially TOC in fisheries under the mandate of UNODC, require criminal procedures at the domestic and international level. ${ }^{17}$

The authors would disagree with those who argue that IUU fishing as TOC, such as Teale Bandaroff. He used to put IUUF and together in one basket, thereby making the matter confusing from the legal and practical point of view. ${ }^{18}$ We believe that crimes in fisheries are not new types of crimes, similar to smuggling, people trafficking, slavery, or money laundering. These are types of crimes which have been addressed at domestic and international level. They are just newly perpetrated in the fisheries sector.

Herewith, we will propose the terminology of "crime in fisheries" as appropriate a legal terminology to deal with the phenomenon of linkage between IUUF and related crimes. Indonesia has experienced different events of crimes related to fisheries, which initially came from IUUF practices. Indonesia has enacted Law Number 45 of 2009, amended from the Law Number 31 of 2004 on fisheries. ${ }^{19}$ However, this law is not concerned with TOC in the fisheries sector. In this regard, we will make the following recommendations. At the domestic level, there must be a regulatory framework that recognises the linkage between fisheries and criminal activities. At the international level, there must be an international cooperation framework that could bring perpetrators from different jurisdictions into one jurisdiction through the existing framework such as Mutual Legal Assistance ("MLA").

16 Ministry of Foreign Affairs of Indonesia, Combating Transnational Crimes, Jan. 20, 2016, available at https://www. kemlu.go.id/en/kebijakan/isu-khusus/Pages/Combating-Transnational-Crimes.aspx. At the multilateral level, Indonesia is consistent with mainstreaming numerous crimes related to the IUU Fishing as new transnational organized crime in various fora, because the IUU Fishing is a complex crime and needs international cooperation to combat it. Furthermore, the international regulation on the IUU Fishing is still considered minimum and not well-structured. See also Z. Gibbons, Indonesia affirms special attention to fisheries crime, ANTARANEWs, May 28, 2016, available at https://otomotif. antaranews.com/berita/563652/indonesia-tegaskan-perhatian-khusus-kejahatan-perikanan. The Minister of Marine Affairs and Fisheries of Indonesia maintained: "ILO once revealed that fishing is considered to be the world's most dangerous occupation, with more than 24,000 fishers lose their lives every year. Unfortunately, it does not stop there - this occupation continues to be the most perilous when we recently discovered an emerging form of crime, that is, transnational organized fisheries crime." See Speech by the Minister of Marine Affairs and Fisheries of the Republic of Indonesia at the High Level Side Event on Preventing and Combatting Transnational Organized Fisheries Crime, May 23, 2016 (on file with the author), available at http://fishcrime.com/joint-high-level-side-event-transnational-organisedfisheries-crime (all last visited on Oct.18, 2018).

17 Chapsos \& Hamilton, supra note 15.

18 BANDAROFF, supra note 14, at 36-42.

19 Palma-Robles, supra note 13 , at 162. 
This paper consists of four parts including Introduction and Conclusion. Part two will analyse the legal and conceptual IUUF, fisheries crime and crime in fishery. Part three will discuss the need for establishing an innovative legal framework at domestic and international levels to address TOC in the fishery sector through Indonesia's experience.

The main data sources of this research were obtained from international agreements on TOC, fisheries law, documents of UNODC, FAO, Interpol, IOM, Indonesian fisheries law, Task Force 115 and secondary data related to crime in the fishery sector.

\section{From IUU Fishing to Transnational Organised Crime in Fishery under Legal Certainty Principle}

Nowadays, there are three terminologies that address IUUF related to TOC, namely IUUF as TOC, fisheries crime as TOC, and TOC in the fishery sector. The terminologies need to be analysed to find out the appropriate legal terminology based on the legal certainty principle. According to the concept of positivism, every legal norm must exist in its objective nature as positive norms and be acknowledged in the form of concrete contractual agreements between citizens or their representatives. ${ }^{20}$ Gustav Radbruch argued that the law must fulfil the three basic elements of legal value, namely justice, expediency and certainty. ${ }^{21}$ Legal certainty can be called as the core of the rule of law in the world. James R. Maxine opined that legal certainty is the international basis of the rule of law. ${ }^{22}$

In this part, the authors will analyse the existing concepts of IUU fishing, fisheries crime and crime in fisheries related to the TOC and then recommend the appropriate legal terminology to address the link between IUU fishing and TOC.

20 According to Hans Kelsen, e.g., legal norms are always created byhuman will. These norms are desirable to become law and must be written in form, issued by the authorized agency and contain the order, See H. KELSEN, PURE THEORY OF LAW 71-9 (2005).

21 R. Alexy, Gustav Radbruch's Concept of Law, available at https://www.upjs.sk/public/media/16913/Gustav\%20 Radbruch\%27s\%20Concept\%20of\%20Law.pdf (last visited on Oct. 20, 2018). See also G. Radbruch, ReCHTSPHILOSOPHIE (1932); The Legal Philosophies of Lask, Radbruch, and Dabin (K. Wilk trans., 1950).

22 J. Maxeiner, Some Realism about Legal Certainty in the Globalization of the Rule of Law, 31 Hous. J. INT'L L. 17 (2008). 


\section{A. The Concept of IUU Fishing}

In 2001, FAO enacted the IPOA-IUU. This plan aims to prevent, deter and eliminate IUUF by providing all states with comprehensive, effective and transparent measures by which to act appropriate regional fisheries management organisations established in accordance with international law. ${ }^{23}$

The terminology of IUUF consist of three terms. The first is 'illegal fishing' which refers to fishing activities conducted by national or foreign vessels in waters under the jurisdiction of a state, without the permission of that state, or in contravention of its laws and regulations. ${ }^{24}$ The second is 'unreported fishing' which refers to activities that are unreported or deliberately misreported to the proper authorities. It means fishing conducted by vessels without nationality, those flying the flag of a country not party to a Regional Fisheries Management Organisation ("RFMO") or, more generally, fishing in a manner that contravenes the regulations of the RFMO or that is inconsistent with state responsibilities for the conservation of living marine resources under international law. ${ }^{25}$ The Third is 'unregulated fishing,' which is conducted by vessels without nationality, or those flying the flag of a country not party to a RFMO within the jurisdiction of that RFMO, or more generally fishing in a manner which contravenes the regulations of the RFMO. This also includes fishing in areas or for fish where there are no applicable conservation or management measures, and "where such activities are conducted in a manner inconsistent with State responsibilities for the conservation of living marine resources under international law.,"26

The IPOA-IUU originally tried to point out that IUU fishing is a threat to effective conservation and management of fisheries, fisheries sustainability and food security. ${ }^{27}$ However, the element of crime in the scope of IUU fishing has not been highlighted. Each FAO member is expected to play a role as a flag state, a coastal state and/or port state to make national regulations to overcome IUU fishing effectively. The IPOAIUU does not mention criminal sanctions for IUU fishing, but suggests a civil sanction imposed by the state. ${ }^{28}$

23 FAO, About IPOA-IUU, available at http://www.fao.org/fishery/ipoa-iuu/about/en (last visited on Oct. 20, 2018).

24 BANDAROFF, supra note 14 , at 12.

25 Id.

26 Id.

27 FAO, supra note 2.

28 IPOA-IUU, §21. 


\section{B. The Link between IUU Fishing and TOC}

The question of IUU fishing and organised crime appeared for the first time at the meeting of the United Nations Open-ended Informal Consultative Process on Oceans and the Law of the Sea ("UNICPOLOS") and the United Nations Convention against Transnational Organised Crime ("UNTOC") in 2008. ${ }^{29}$ After the meeting, the UNGA began to consider the possible link between illegal fishing and TOC, which was set in Resolution on Sustainable Fisheries in 2008. ${ }^{30}$

There is a growing trend amongst states, international bodies and intergovernmental organisations to recognise IUUF as a serious and highly organised crime. For examples, the Indonesian government initiated a Forum Group Discussion on Illegal Fishing as TOC in Vienna on October 29, 2015. ${ }^{31}$ In addition, Teale Bondaroff stressed on the importance of reconceptualising IUU fishing as a form of TOC. $^{32}$ Furthermore, Ionne Chapsos hyphotised illegal fishing through the lens of TOC and concluded that IUU fishing could be classified as TOC. ${ }^{33}$

Illegal fishing may be classified as TOC mainly because it is involved in other crimes including the perpetrators of IUUF in large scale fishing. Article 3 of UNTOC that stipulates that an offence is transnational in nature if it is committed: (a) in more than one state; (b) in one state but a substantial part of its preparation, planning, direction or control takes place in another state; (c) in one state but involves an organised criminal group that engages in criminal activities in more than one state; or (d) in one state but has substantial effects in another state. ${ }^{34}$

The government or the authors have classified IUUF as TOC based on the facts that IUUF perpetrators also committed crimes and have met the characteristic of TOC. $^{35}$ They do not consider the IPOA-IUUF instrument that regulates IUU fishing as

29 UNODC, Conference of the Parties to the United Nations Convention against Transnational Organized Crime, Vienna, Oct. 8-17, 2008 (4th sess.), CTOC/COP/2008/19, - 210, available at https://www.unodc.org/documents/treaties/ CTOC_COP_19_Report___edited_version.pdf (last visited on Oct. 20, 2018).

30 G.A. Res. 63/112, U.N. Doc. GA/RES/63/112 (Nov. 25, 2008), available at https://undocs.org/A/RES/63/112 (last visited on Oct. 20, 2018).

31 R. Budiman, The way Forward: Vienna's perspective on Global Process and initiatives to Fight against Fisheries Crime, available at http://fishcrime.com/wpcontent/uploads/2016/10/Presentation_Rachmat-Budiman.pdf (last visited on Aug. 25, 2018).

32 BANDAROFF, supra note 14 , at. 7

33 Chapsos \& Hamilton, supra note 15.

34 UNTOC art. 3(2).

35 The Indonesian government and the authors declared the IUUF as TOC. E.g., Bandaroff has included the IUUF as TOC because it meets the 11 categories. See M. SAntosa, Indonesia's Multi-Door Approach in Combating Fisheries Crime: The Fight against Fisheries And Associated Crimes in Indonesia 14 (2016), available at http:/fishcrime.com/ wp-content/uploads/2016/10/Presentation_Mas-Achmad-Santosa.pdf (last visited on Oct. 25, 2018). 
a fisheries management matter.

Reviewing the concept of IUUF as TOC based on legal positivism, it cannot be justified as an appropriate legal concept because there is mixed concept between IUUF and TOC. The international community acknowledges that IUUF would fall in the domain of FAO regarding fisheries management and food security. ${ }^{36}$ However, the concept of IUUF as TOC is not accepted by the international community.

\section{Analysis of the Concept of Fisheries Crime}

Crimes on IUUF vessels occur in various regions including West Africa, Southeast Asia, the Indian Ocean and the Pacific Ocean. ${ }^{37}$ The form of human right abuses on IUUF vessels are physical violence, forced labour, exploitation, substandard safety and health. ${ }^{38}$ The UNODC reported crimes committed by the IUUF actors in the fishing industry include, inter alia, human trafficking, migrant smuggling, corruption, illicit drugs and piracy. ${ }^{39}$

In 2013 , the concept of fisheries crime was introduced by Interpol. ${ }^{40}$ To date, however, there is no legal definition of fisheries crime. The UNODC defines fisheries crime as "a wide range of offences along the value and supply chain of the fisheries sector, on land and at sea." ${ }^{41}$ It includes document fraud, tax evasion, corruption, money laundering, human trafficking and illegal fishing. ${ }^{42}$ According to the Indonesian

36 FAO, International Plan of Action to Prevent, Deter and Eliminate Illegal, Unreported and Unregulated Fishing (2001), available at $\mathrm{http}: / / w w w . f a o . o r g / 3 / a-y 1224 e . p d f$. Point 1 of IPOA-IUU mentions:

In the context of the Code of Conduct for Responsible Fisheries and its overall objective of sustainable fisheries, the issue of illegal, unreported and unregulated (IUU) fishing in world fisheries is of serious and increasing concern. IUU fishing undermines efforts to conserve and manage fish stocks in all capture fisheries. When confronted with IUU fishing, national and regional fisheries management organizations can fail to achieve management goals. This situation leads to the loss of both short and long-term social and economic opportunities and to negative effects on food security and environmental protection. [Emphasis added]

For the implementation of IPOA IUU, see FAO, Implementation of the International Plan of Action to Prevent, Deter and Eliminate Illegal, Unreported and Unregulated Fishing (2002), available at http://www.fao.org/3/a-y3536e.pdf (all last visited Oct. 4 2018). Every members of FAO is responsible for implementing the IPOA IUU in national legislation that called National Plan of Action.

37 EJf, All at Sea, The Abuses of Human Right Aboard Illegal Fishing Vessels (2010), available at https:// ejfoundation.org//resources/downloads/report-all-at-sea_0_1.pdf (last visited on Aug. 28, 2018).

38 Id.

39 UNODC, supra note, 5.

40 E. Coning, Fisheries Crime, in Handbook of Transnational Environmental Crime 146-65 (L. Elliott \& W. Schaedla eds., 2016).

41 UNODC, Fisheries Crime, available at http://www.unodc.org/unodc/about-unodc/campaigns/fisheries crime.html (last visited on Aug. 3, 2018).

42 Id. 
government, "fisheries crime and fisheries related crime are terms of criminology which cover all crimes committed along the whole value chain of fishery industry." 43

Fisheries crime is considered as a new crime and has not been regulated in international fisheries law such as in the United Nations Convention on the Law of the Sea ("UNCLOS") 1982, the UN Fish Stock Agreement, FAO Compliance Agreement, UNTOC 2000, and Convention on International Trade in Endangered Species of Wild Fauna and Flora ("CITES") 1963. Similarly, in such regional agreements as the Western and Central Pacific Tuna Commission ("WCPC"), the Indian Ocean Tuna Commission ("IOTC") and the Convention for the Conservation of Southern Bluefin Tuna ("CCSBT"), all international lawyers addressed the management and sustainability of fisheries, but did not mention the "fisheries crime. ${ }^{44}$

Regarding the fisheries crime as TOC will face obstacles globally for the following two reasons. First, the state must formulate the elements of 'fisheries crime' as a new crime. Second, 'fisheries crime' has never been regulated in international law. ${ }^{45}$ There is no legal basis to realise legal certainty. Actually, however, the substance of 'fisheries crime,' such as corruption, human trafficking, money laundering, people smuggling and forced labour, has been regulated in international law. Hence, the authors would propose the terminology 'crime in fisheries' to bridge the conceptual link between IUU fishing and related crimes.

\section{Understanding Crime in Fishery as Appropriate Legal Terminology}

IUU fishing is understood as a fisheries management issue, which falls under the mandate of FAO. Fisheries crime is a new concept without legal basis. In addition to fisheries crime, "crime in fisheries" was implicitly used by the UNODC in its 2011 report titled, Transnational Organised Crime in Fishing Industry. ${ }^{46}$ In 2016, the Organisation for Economic Co-operation and Development ("OECD”), FAO and the UNODC held a conference and workshop with the theme: Combating Tax Crime and

43 S. Astuti, Protecting Our Waters from Fisheries Crime, JAKARTA Post, June 14, 2016, available at http://www. thejakartapost.com/academia/2016/06/14/protecting-our-waters-from-fisheries-crimes.html (last visited on Aug. 28, 2018).

44 A. Oegroseno, Capacity Building Implementation of International and Regional Instrument to tackle Fisheries Crime, available at $\mathrm{http}: / /$ fishcrime.com/wp-content/uploads/2016/10/Presentation_Havaz-Oegroseno.pdf (last visited on Aug. 27, 2018).

45 Id. See also I. Crisan, The Principles of Legality "Nullum Crimen, Nulla Poena Sine Lege" and Their Role, 5 EFFECTIUS Newsletter (2010), available at http://effectius.com/yahoo_site_admin/assets/docs/The_principles_of_legality_ nullum_crimen_nulla_poena_sine_lege_and_their_role_Iulia_Crisan_Issue5.16811416.pdf (last visited on Oct. 3, 2018).

46 UNODC, supra note 5. 
Other Crimes in the Fisheries Sector. ${ }^{47}$ Moreover, UNODC and other organisations tend to equate the terminology of fisheries crime and crime in fishery sector. It can be seen in the UNODC report titled, Stretching the Fishnet: Identifying Opportunities to Address Fisheries Crime 2017. ${ }^{48}$ The UNODC regards fisheries crime as TOC. ${ }^{49}$

Why should we use the terminology of crime in the fishery sector? First, crimes in fisheries are not new types of crimes. They normally include smuggling, people trafficking, slavery or money laundering. These are types of crimes that have existed long at domestic and international level. They are just recently perpetrated in the fisheries sectors, sometimes almost in the whole industrial chains, for instance, recruiting slaves, forcing them to work at sea for years without pay, torturing them, and using child labour in processing the catch. These are not acts under IUUF, but criminal acts that have all been addressed by national or international law of fisheries. Moreover, "crimes in fisheries" are often involved in different nationalities, different locus delicti that are across national boundaries, whose fruit are enjoyed transnationally. [Emphasis added] These criteria fall within the definition of transnational crimes and TOC. ${ }^{50}$ Distinguishing the concept of fisheries crime and CIFS in the perspective of 'legal certainty' is extremely important because 'crimes' in the fishery sector have been regulated by international law, as follows:

a. Human trafficking has been regulated in the Protocol to Prevent, Suppress and Punish Trafficking in Persons, especially Women and Children of 2000.

b. Migrants smuggling has been regulated in Protocol against the Smuggling of Migrants by Land, Sea and Air Supplementing the United Nations Convention against Transnational Organised Crime 2000.

c. Forced Labour has been regulated in International Labour Organisation (ILO) Convention 1930 (No. 29) and Work in Fishing Convention No.188 2007.

d. Corruption has been regulated in UNTOC of 2000 and United Nations Convention against Corruption of 2004.

e. Money laundering has been regulated in UNTOC of 2000.

f. Human Rights violation has been regulated in several international instruments (Universal Declaration on Human Rights, International Covenant on Civil, and

47 OECD, Combating Tax Crime and Other Crimes in the Fisheries Sector, available at http://www.oecd.org/tad/events/ combating-crimes-fisheries-conference-2016.htm (last visited on Aug. 28, 2018).

48 UNODC, Stretching the Fishnet: Identifying Opportunities to Address Fisheries Crime May 2017, available at http:// fishcrime.com/wp-content/uploads/2017/07/Stretching-the-Fishnet.pdf (last visited on Aug. 31, 2018).

49 Id. at. 12.

50 UNODC, supra note 5. See also EJF, supra note, 37; R. Mc. Dowell et al., AP Investigation: Slaves May Have Caught the Fish You Bought, AP, Mar. 25, 2015, availabe at https:/www.ap.org/explore/seafood-from-slaves/ap-investigationslaves-may-have-caught-the-fish-you-bought.html (last visited on Oct. 3, 2018). 
A. Yuliantiningsih et al.

Political Rights, The United Nations Convention against Torture and Other Cruel, Inhuman or Degrading Treatment or Punishment of 1984, Convention on The Rights of Child of 1989, etc.)

Second, there is a legal basis to mainstream the terminology of crime in fishery in the UNGA, as the International Ocean Rim Association ("IORA") has agreed on this terminology in the Jakarta Concord of 2017. In Point 16 (a), the Jakarta Concord set the states to strengthen regional cooperation to address transboundary challenges including piracy, armed robberies at sea, terrorism, trafficking in persons, people smuggling, irregular movement of persons, illicit drug trafficking in wildlife, crimes in the fisheries sector and environmental crime. Table 1 shows the differences between the concepts of IUUF as TOC, fisheries crime as TOC, and crime in fishery sector.

Table 1: The Differences between the Concept of IUU Fishing as TOC, Fisheries Crime as TOC and Crime in the Fishery Sector

\begin{tabular}{|c|c|c|c|}
\hline Terminology & IUUF as TOC & $\begin{array}{l}\text { Fisheries Crime } \\
\text { as TOC }\end{array}$ & Crime in Fisheries \\
\hline Definition & $\begin{array}{l}\text { Referring to Paragraph } \\
3 \text { IPOA-IUU F }\end{array}$ & $\begin{array}{l}\text { Referring to a wide } \\
\text { range of offences } \\
\text { along the value and } \\
\text { supply chain of } \\
\text { the fisheries sector. }\end{array}$ & $\begin{array}{l}\text { Referring to all crimes } \\
\text { committed in the fishery } \\
\text { sector; it has the same } \\
\text { substance with 'fisheries } \\
\text { crime'; but the new thing } \\
\text { is laid on 'the sector' } \\
\text { in fishery. }\end{array}$ \\
\hline Domain & FAO & UNODC & UNODC \\
\hline Legal basis & IPOA -IUUF & None & Jakarta Concord 2017 \\
\hline Obstacles & $\begin{array}{l}\text { As a matter of } \\
\text { fisheries management, } \\
\text { fisheries sustainability } \\
\text { and food security. }\end{array}$ & $\begin{array}{l}\text { - Considered as } \\
\text { the new crime, } \\
\text { - The states must } \\
\text { formulate the } \\
\text { elements of the } \\
\text { 'fisheries crime' } \\
\text { as a new crime }\end{array}$ & \\
\hline $\begin{array}{l}\text { Reviewing } \\
\text { with Legal } \\
\text { certainty } \\
\text { principle }\end{array}$ & $\begin{array}{l}\text { Not appropriate } \\
\text { legal concept } \\
\text { because of mixing } \\
\text { of the concept of IUU } \\
\text { fishing and TOCs }\end{array}$ & $\begin{array}{l}\text { Has no legal basis } \\
\text { in international } \\
\text { law. }\end{array}$ & $\begin{array}{l}\text { - Appropriate legal concept, } \\
\text { as 'crime in fisheries' are } \\
\text { not new types of crimes. } \\
\text { It has been regulated in } \\
\text { international and national } \\
\text { law. The new thing is only } \\
\text { the 'sector' in fisheries. } \\
\text { - Has a legal basis in the } \\
\text { Jakarta Concord } 2017 \text {. }\end{array}$ \\
\hline
\end{tabular}

Compiled by the authors. 


\title{
III. Innovative Legal Framework at the National and International Levels to Address TOC in Fishery Sector: Indonesia's Experiences
}

\begin{abstract}
A. The Emergence of Awareness on IUU Fishing and Related Crimes
Generally, the international community, including Indonesia, regulates the problem of IUUF as a fisheries management issue. In the other sense, however, it shows that IUUF is related to other crimes and TOC. The Indonesian government began to mainstream fisheries crime as TOC based on the two following factors.
\end{abstract}

\section{Evaluation and Analysis Results against Ex-Foreign Vessels in 2015}

The Indonesian government conducted an Anev regarding ex-foreign vessels based on the MMAF Regulation Number 56 of 2014 concerning the Moratorium of Provision of Fishing Permit in the Indonesian Fisheries Management Area. Task Force 115 is assigned to conduct analyses and evaluations of ex-foreign vessels whose permits are still valid. Anev was conducted for eight months from March to October 2015. The audit covers the following aspects of compliance: legality of the incorporation of limited liability corporations; compliance with ownership of tax identification numbers; domicile of limited liability companies/corporations; obligation to activate vessel monitoring system ("VMS")/automatic information system (AIS); compliance with having/ partnering with a fish processing unit; landing of illegal catches; violation of ship transfer at sea; using crew and foreign captains; using prohibited fishing gear; violation of fishing grounds; tax payment compliance; tax reporting compliance; ships and companies indicated as committing fisheries and fisheries-related crimes. ${ }^{51}$

According to the document analysis and field inspections, 1132 vessels have violated the fisheries regulations. ${ }^{52}$ Then, the Indonesian government began to use the terminology of 'fisheries crime' and "fisheries related crime."

The 'fisheries crime' found in Indonesia are as follows: using foreign crew and captains; not landing fish in fishing ports; human trafficking and forced labour; catching fish outside the fishing area; using prohibited fishing gear; transporting

51 IOM, supra note 8, at. 14-5.

52 Y. Husen, Indonesia's Approach in Tackling IUU fishing : Strategy on the Prevention and Eradication of IUU Fishing \& Post-Moratorium Policies, available at http://www.fishcrime.info/assets/Uploads/Yunus-Husein-IndonesianApproach-To-Tackling-Fisheries-Crime.pdf (last visited on Oct. 20, 2018). 
goods to and from Indonesian territory without going through customs; transhipment at sea, falsification of diary records of fishing vessels and unreporting the catch fishing. ${ }^{53}$

In addition, Anev is committed to the "fisheries related crimes," namely corruption, money laundering, tax violations, customs-related crimes, immigrationrelated crimes, illicit trade in drugs and violations of human rights (human trafficking, forced labour and child labour). The human rights violations in the fishing industry in Indonesia include, inter alia, murder, sexual crime, occupational health and safety violations, working beyond the time limit, crimes against physical and mental, no employment social security, inhumane work situation, underage child workers, recruitment of workers through kidnapping, etc. ${ }^{54}$

Since the Anev in 2015, the Indonesian government has begun to use the terminology of fisheries and fisheries related crimes even though there is no generally accepted legal definition. It considered fisheries crime as the new crime ${ }^{55}$ The authors would argue that the use of the terminology of fisheries crime and fisheries related crimes by the Indonesian government must be reviewed because it is not in accordance with international law.

\section{The Emergence of the Cases on the Link of IUUF and Related Crimes in Indonesia}

There are some cases in Indonesia on the link between IUUF and related crimes that can be considered as TOC. Noticeable examples are the Benjina case and the Viking case. First, the Benjina case has attracted international attention since the AP reported the human trafficking link in the fishing industry in Benjina, Indonesia titled, Was Your Seafood Caught by Slaves? which describes the inhumane treatment faced by the crew members in Benjina. ${ }^{56}$ Following the report, the Anev team conducted an inspection there. The investigation found that Pusaka Benjina Resources ("PT PBR") committed human rights violations in the form of child labour, human trafficking, living conditions below standards, physical and mental torture, 18-20 working hours, unpaid works and fraud..$^{57}$

The Benjina case is an evidence that the IUUF perpetrators commit other crimes

53 IOM, supra note 8 at 15 .

54 Id. at 16.

55 Gibbons, supra note 16.

56 See Was Your Seafood Caught By Slaves? AP Uncovers Unsavory Trade, NPR News, Mar. 27, 2015, available at https://www.npr.org/sections/thesalt/2015/03/27/395589154/was-your-seafood-caught-by-slaves-ap-uncoversunsavory-trade; M. Dowell, et al., Seafood from Slaves: An AP investigation helps free slaves in the 21st century, AP, 2015, available at https://www.ap.org/explore/seafood-from-slaves (all last visited on Oct. 20, 2018).

57 IOM, supra note 5 
with transnational element, as well. The ownership of companies by Thailand is one of the characteristics of organised transnational, illegal fishing operators. The fishing vessels were formerly owned by Thailand and several registering countries with an open system such as Panama. In order to operate in Indonesia, the shipowner companies in Thailand bribed the local authorities in Indonesia, replacing Thai flag with Indonesian one. Violations committed by PT PBR include: committing criminal acts of trafficking and slavery, using child labour, smuggling people and goods, transferring illegal cargo in the sea, using illegal fishing gear (trawl), falsifying documents of ships and crew, and conducting illegal fuel transactions. ${ }^{58}$

There are many transnational elements in the Benjina case. For example, the workers were recruited from various countries and forced to work illegally in Indonesia, when a front company was established and illegal transhipment of fish was carried out in the Exclusive Economic Zone ("EEZ") and border area of Indonesia. Ultimately, the Indonesian government should capture a global supply chain and handle a legitimate fish supplier, unaware of the origin of the human charge and casualties behind it. Victims of trafficking came from several countries, namely Thailand, Myanmar, Laos, Cambodia and Vietnam. One of the owners of PT PBR is a company registered in the British Virgin Island affiliated with a Hong Kong company, while most of the vessels are made in Thailand and fly the flags of Indonesia, Thailand and Papua New Guinea. ${ }^{59}$

\section{FV Viking Case}

Viking is owned by companies registered in two countries and operated by agents in Southeast Asia to catch fish in African coasts and export caught fish through transhipment and ship to various regions of the world. It has been operating with at least 13 different names in order to avoid the officers in international waters. ${ }^{60} \mathrm{FV}$ Viking is operated with 12 different names and has at least eight state flags. The ship was sought by 13 countries and the Interpol. ${ }^{61}$

Viking was captured by the Indonesian Navy on February 26, 2016 in the 12.7-

58 M. Santosa, The Fight against Fisheries and Associated Crimes in Indonesia, available at http://fishcrime.com/wpcontent/uploads/2016/10/Presentation_Mas-Achmad-Santosa.pdf (last visited on Aug. 29, 2018).

59 Id.

60 P. Parameswaran, Indonesia Blows Up Interpol's Most Wanted Ship, Diplomat, Mar. 16, 2016, available at https:// thediplomat.com/2016/03/indonesia-blows-up-interpol-most-wanted-ship (last visited on Aug. 29, 2018).

61 S. Mollman, An illegal Fishing Vessel Wanted by 13 Nations has Finally Been Destroyed by Indonesia, QuARTz, Mar. 15, 2016, available at https://qz.com/639408/an-illegal-fishing-vessel-wanted-by-13-nations-has-finally-beendestroyed-by-indonesia (last visited on Aug. 29, 2018). 
mile EEZ of Tanjung Uban, Bintan, Riau Province. ${ }^{62}$ This ship entered Indonesia without prior notice and turned off their Automatic Identification System ("AIS"). Its crew consisted of five people from Argentina, Peru and Myanmar and six from Indonesia. $^{63}$ The Illegal Fishing Task Force assisted by the Multilateral Investigation Support Team ("MIST") from Norway and Canada also found several issues including:
a. FV Viking was a stateless vessel;
b. Reports on fishing and navigation computers, as important tools to find the location of FV Vikings fishing, were not found on board;
c. The found document revealed that the caught fish are often landed in Thailand; and
d. FV Viking was related to fishing companies in Spain. ${ }^{64}$

The transnational element of the FV Viking case is its 'ownership.' Viking was owned by Spanish and Panamanian companies and operated by agents in Southeast Asia who were domiciled in several countries. The captain was a Chilean citizen. The fish was caught in various regions of the world waters and exported to Hong Kong, Malaysia, Vietnam and Taiwan through investment companies in South Africa. ${ }^{65}$

The Benjina case and the FV Viking case shows that IUU fishing perpetrators committed organised crime and involved many countries, so that it is necessary to develop an innovative legal framework at domestic and international level.

\section{B. Mainstreaming IUUF as TOC to "TOC in Fishery" at International Level: Indonesia's Experience}

Since 2015, Susi Pudjiastuti has proposed illegal fishing as a transnational crime. ${ }^{66}$ Furthermore, the Indonesian government has delivered an official statement regarding the need for cooperation to overcome TOFC at the 25th session of the CCPCJ on May

62 L. Snook, Indonesian Navy scuttles fv-Viking Worlds Wanted IUU Pirate Fishing Ship, AEC NEws, Mar. 16, 2016, available at https://aecnewstoday.com/2016/indonesian-navy-scuttles-fv-viking-worlds-wanted-iuu-pirate-fishingship/\#axzz5Sq3A5M32 (last visited on Oct. 3, 2018).

63 COLTO, IUU Viking sunk by Indonesian authorities, Mar. 15, 2016, available at https://www.colto.org/2016/03/15/ iuu-viking-sunk-by-indonesian-authorities (last visited on Aug. 29, 2018).

64 H. Purwanto, Indonesian Goverment to Sink Interpol Fugitive Vessel FV Viking, ANTARA News, Mar. 13, 2016, available at https:/en.antaranews.com/news/103636/indonesian-government-to-sink-interpol-fugitive-vessel-fv-viking. See also Y. Husein, Indonesia's Fight against Illegal, Unreported and Unregulated Fishing, available at http://pesforum. org/docs/2018/DFC_Indonesia.pdf (last visited on Oct. 3, 2018).

65 Id.

66 Widakuswara, supra note 11. 
23, 2016. Then, Indonesia argued that emerging forms of crime, in particular 'fisheries crime' and "fisheries related crime" should be paid proper attention, inter alia, by putting them in the same basket as other manifestations of TOC. ${ }^{67}$ Several states, particularly Indonesia, see the following advantages if TOFC is regulated in the TOC framework: ${ }^{68}$

1. Facilitating international cooperation in the field of law enforcement.

2. Acceleration the adjustment of the national legal system with UNTOC principles (harmonisation of legislation);

3. Facilitating the implementation of extraterritoriality principles; ${ }^{69}$

4. Acceleration extradition and reciprocal assistance processes in criminal matters; ${ }^{70}$

5. Imposition of various kinds of sanctions with greater deterrent effects including economic sanctions; ${ }^{71}$

6. A more extended period before expiration; ${ }^{72}$ and

7. Providing of a network to exchange of data/information and analysis.

A historical explanation of the efforts of Indonesia to mainstream IUUF to "TOC in fishery" in international fora is provided below.

\section{Focus Group Discussion ("FGD")}

Indonesia initiated a discussion about "Illegal Fishing as TOC" by holding a FGD on Illegal Fishing as TOC in Vienna on October 29, 2015. FGD was initiated by the Indonesian Permanent Representative in Vienna and was attended by 14 representatives of countries with similar views on Indonesia on the issue of illegal fishing. Countries with the same view are called "friends of fisheries" such as Australia, Colombia, Costa Rica, Kenya, Mexico, Norway, Oman, Indonesia, and the US. The UNODC representative and the World Wide Fund and experts participate in this group as observers. ${ }^{73}$

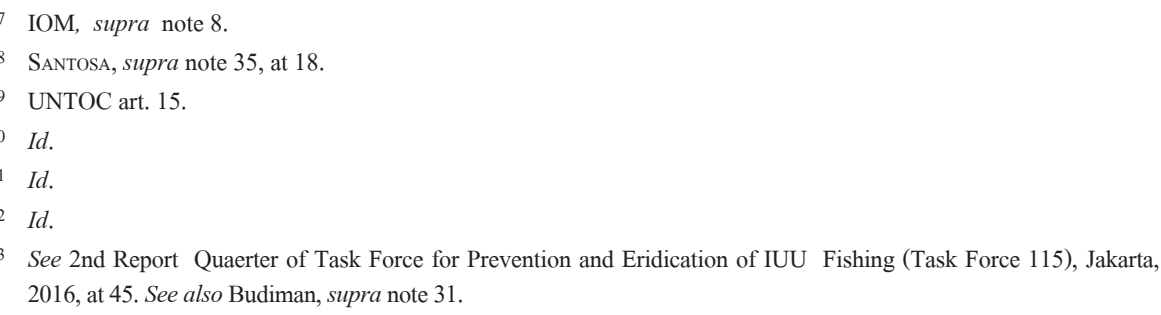




\section{International Symposium of FishCRIME}

The South African Department of Agriculture organised the first FishCRIME Symposium, Forestry and Fisheries on October 12-13, 2015 in Cape Town. Two hundred delegates from 31 countries attended the symposium. This symposium was the first step for starting a global dialogue among various experts, academics, governments and international agencies on the topic of fisheries crime. The aim was to raise awareness that illegal fishing is only one aspect of transnational criminal activities, which are well organised and well-funded. They occur in the oceans around the world, so that new approaches are required to tackle fisheries crime. ${ }^{74}$ The 2 nd FishCRIME was held in Yogyakarta on October 10-11, 2016 with 45 countries. The symposium aimed at synchronising the vision of countries for joint law enforcement and strengthening cooperation in law enforcement to eradicate fisheries crime. ${ }^{75}$ The MMAF, together with Task Force 115, continues to encourage fisheries crimes and criminal acts related to fisheries to be considered as transnational organised crimes.

\section{Commission on Crime Prevention and Criminal Justice ("CCPCJ")}

In the 25th session of the CСPCJ on May 13-27, 2016, in Vienna, the Indonesian government through the MMAF fought for the concept of 'fisheries crime's as TOC. Susi Pudjiastuti maintained that countries recognise the existence of TOFC as a growing international crime, which threatens all countries, as many countries have no commitment to fight against crime in the fisheries sector. The Indonesian government organised the "High-Level Side Event TOFC" to increase awareness and support from various countries to eradicate fisheries crime. ${ }^{76}$

\section{Regional Conference on the Establishment of Regional Convention against IUU Fishing and Its Related Crimes}

Indonesia's efforts at the international level have been strengthened by holding regional meetings on the Establishment of Regional Convention against IUU Fishing and Its Related Crimes on May 18-20 (Bali) and October 12-13 (Yogyakarta) of 2016, respectively. They were held to gain the support of countries in combating 'fisheries crime' through the establishment of regional instruments that give more attention to

74 The International Symposium on FishCRIME, available at http://fishcrime.info/assets/FishCRIME2015Record.pdf (last visited on Oct. 3, 2018).

75 CCPCJ, Outcome of the 2nd International Symposium on Fisheries Crime (Oct. 10-11, 2016), Yogyakarta, Indonesia, available at $\mathrm{http}: / /$ fishcrime.com/wp-content/uploads/2017/06/CRP-Final.pdf (last visited on Sept. 5, 2018).

76 KKP, Joint High Level Side Event 'Transnational Organised Fisheries Crime' (2016), available at http://fishcrime.com/ joint-high-level-side-event-transnational-organised-fisheries-crime (last visited on Aug. 29, 2018). 
the law enforcement aspect. ${ }^{77}$ The conference was attended by representatives from 18 countries, several experts and a number of international organisations such as FAO, the Interpol and the UNODC. ${ }^{78}$

\section{The Our Oceans Conference}

The Our Oceans Conference ("OOC") is a gathering forum for the top officials of each country to exchange their experiences in protecting marine ecosystems. The OOC has been held annually since 2014. The Indonesian government of Indonesia is campaigning on the importance of the recognition of TOFC in various international fora including the OOC. The Indonesian MMAF campaigned for illegal fishing to be acknowledged as an organised transnational fishery crime on June 6, 2017 at the OOC. $^{79}$

The MMAF of Indonesia, together with Norway, the UNODC and the Interpol, organised a high-level side event on TOC in Fisheries Sector 'Fisheries Crime.' The Indonesian government has campaigned on the importance of TOFC under the premise that illegal fishing is organised transnational fishery crime. ${ }^{80}$

\section{Indian Ocean Rim Association ("IORA") 2017}

On March 5-6, 2017, the IORA member States held a meeting in Jakarta, Indonesia. The meeting resulted in the Jakarta Concord as a legal basis of using the terminology "crime in fisheries" sector. The Jakarta Concord stipulated in Point 16 (a) the "crime in fisheries" sector. It enumerates "regional integration of cooperation to address transnational challenges including justice, armed robberies at sea, terrorism, trafficking in persons, smuggling people, irregular movement of persons, illicit drug trafficking in wildlife, crimes in the fisheries sector and environmental crime." The Jakarta Concord is a strategic document of the IORA that serves a guide for member states in responding to global challenges. ${ }^{81}$

77 See Indonesia Leads the Establishment of a Regional Cooperation to Combat Crimes in Fisheries Sector, UN Ocean Conference, available at https://oceanconference.un.org/commitments/?id=15127 (last visited on Aug. 22, 2018).

78 Id.

79 KKP, Side Event Transnational Organized Crime in the Fisheries Industries (Fisheries Crime) on June 6, 2017, available at https://kkp.go.id/artikel/2377-tranational-organized-crime-in-the-fisheries-industries-fisheries-crime (last visited on Oct. 24, 2018).

80 Id.

81 See IORA Leaders Summit held in Jakarta, GKTodAY, Mar. 9, 2017, available at https://currentaffairs.gktoday.in/ioraleaders-summit-held-jakarta-03201742236.html (last visited on Sept. 3, 2018). 


\section{Regional Conference on the Establishment of a Regional Cooperation Agreement against Crimes related to Fisheries}

Indonesia has held Regional Conferences on the Establishment of Regional Convention against IUU Fishing and Its Related Crimes. Both meetings in Bali and Yogyakarta in 2016 supported the countries in combating fisheries crime through the establishment of regional cooperation.

Table 2: The Chronology of Mainstreaming the Concept of IUUF as TOC to TOC in the Fishery Sector in Indonesia

\begin{tabular}{|c|c|c|}
\hline Date & International Forum & $\begin{array}{l}\text { The concept to be } \\
\text { mainstreamed }\end{array}$ \\
\hline Oct. 13, 2015 & Symposium FishCrime I & Fisheries Crime \\
\hline Oct. 29,2015 & FGD on Illegal Fishing as TOC & Illegal Fishing as TOC \\
\hline Oct. 16, 2016 & Symposium FishCrime II & TOFC \\
\hline May 23-27 2016 & CСРCJ ke-25 & TOFC \\
\hline Sept. 15, 2016 & OOC & TOFC \\
\hline Mar. 5-7, 2017 & IORA & Crime in the Fishery Sector \\
\hline Sept. 18-19, 2017 & $\begin{array}{l}\text { Regional Conference on the } \\
\text { Establishment of a Regional } \\
\text { Cooperation Agreement against } \\
\text { Crimes Related to Fisheries }\end{array}$ & Crimes Related to Fisheries \\
\hline
\end{tabular}

Complied by the authors.

As of today, the Indonesian government does not have a firm basis on the mainstream concept at the international level. Initially, the Indonesian government used the term "illegal fishing as TOC" without considering the feasibility to be accepted by the international community. Furthermore, the Indonesian government called the international community to recognise the concept of TOFC as the new crime combining illegal fishing and crime in fishery. ${ }^{82}$ Without appropriate legal terminology, however, it makes the matter confusing from the legal and practical perspective. Last, the Jakarta Concord addressed a legal basis for the terminology of crime in fishery, so that it needs a strategy for Indonesia to fight the acceptable

82 See Indonesia Lobbied UN to Make IUU Fishing a Transnational Organized Crime, Stop Illegal Fishing Press/ Link, May 8, 2017, available at https://stopillegalfishing.com/press-links/indonesia-lobbies-un-make-iuu-fishingtransnational-organized-crime (last visited on Oct. 20, 2018). 
concept by the international community consistently. ${ }^{83}$

\section{Legal Framework to Address TOC in the Fishery Sector: Indonesia's Perspective}

The Indonesian government is asked to develop innovative legal framework to address TOC in fishery sector at domestic and international levels. At the domestic level, in line with the efforts to get the recognition for the concept of TOFC from the international community, the Indonesian government has enacted Law Number 45 of 2009 and Law Number 31 of 2004 on Fisheries.

However, there are four weaknesses that need to be revised. First, the category of 'fisheries crime' in Law number 45 of 2009 on Fisheries only covers crime against damage to the ecosystem. According to Article 1(1) of Law No. 45 of 2009, fisheries include "all activities related to the management and utilisation of fish resources and the environment ranging from preproduction, production, processing to marketing, carried out in a fisheries business system." Referring to this article, the categories of 'fisheries crime' must be extended to address TOC in the fishery sector. The categories of 'fisheries crime' can be divided into 'fisheries crime' and 'crime in the fisheries sector.' 'Fisheries crime' involves any violations against fishery act, while "crimes in the fisheries" sector include all illegal activities carried out in the fisheries sector chain. Hence, they can occur at sea or on land. The value chain of the fisheries sector includes the stages of preparation, capturing, production, landing, transportation and sales. ${ }^{84}$

Second, criminal penalties in the form of corporal punishment range from 1 to 10 years in prison and the fines range from Rp 1,500,000.000,000 to Rp 20.000,000,000. ${ }^{85}$ Unfortunately, the perpetrators were only sentenced to get mild punishment. For example, MV Haifa stole 900,702 tons of fish and made the country suffer a loss of Rp 70 billion, but the Ambon District Court sentenced only one-year imprisonment and a fine of Rp 200 million (USD14,929). ${ }^{86}$

83 The Indian Ocean Rim Association, Promoting Regional Cooperation for A Peaceful, Stable and Prosperous Indian Ocean (Jakarta Concord), Point 16, available at https://www.kemlu.go.id/Buku/JAKARTA\%20CONCORD_FINAL_ not $\% 20$ signed.pdf (last visited on Oct. 24, 2018).

84 Fisheries Act Number 45 of 2009, art. 1(1), availabe at http://pelayanan.jakarta.go.id/download/regulasi/undangundang-nomor-45-tahun-2009-tentang-perikanan.pdf (last visited on Oct. 24, 2018).

85 Fisheries Law Number 31 of 2004 jo Act Number 45 of 2009 on Fisheries, arts. 84-100, available at http://www.dpr. go.id/dokjdih/document/uu/32.pdf(last visited on Sept. 3, 2018).

86 See Decision of Ambon District Court Number 01/Pid.Sus/PRK/2015/PN.AMB, available at https://putusan. mahkamahagung.go.id/putusan/f885755d830aeafe08185cf0ea69d874 (last visited on Oct. 3, 2018). See also Husein, supra note 9. 
Third, according to Article 71 of the Fisheries Law, in absolute competence, it is determined that the authority of the fishery court is to deal with fisheries, not covering criminal acts related to fisheries. The ideal fishery court model should be the authority fishery court to cover all criminal acts that occur in the fishery sector. ${ }^{87}$

Fourth, Article 101 of the Fisheries Law stipulates that only the board can be punished, so that it is difficult to punish the the corporates. It is necessary to revise this provisions adding the section concerning corporate responsibility for the crimes.

In addition, the Indonesian government should strengthen the law enforcement to address crime in the fishery sector. The multi-door approach can be used if IUUF perpetrators also commit other crimes. This approach means that the entry point into the investigation is via any criminal offence in any jurisdiction along the value chain. ${ }^{88}$ The law enforcers can apply related laws in the fishery sector such as immigration laws, human trafficking law, corruption, anti-money laundering law, environmental law, labour law, criminal law, etc. ${ }^{89}$

At the international level, meanwhile, the UNTOC is one of the most important multilateral mechanism to combat transnational crimes. Generally, states have often used the UNTOC's legal framework for international cooperation in combating TOC such as corruption, people smuggling, money laundering and arms smuggling through transfer of proceedings, cooperation in the restraint and forfeiture of proceeds of crime, extradition, transfer of sentenced prisoners, and MLA. ${ }^{90}$ There are three forms of international cooperation in the field of law: (1) extradition involving fugitive person; (2) transfer of sentenced person (better known as a transfer of prisoners); and (3) MLA in criminal matters concerning internal legal actions, the process of investigation, prosecution and trial in court hearings and deprivation of crime. $^{91}$ There are six forms of cooperation in international criminal law enforcement, which are extradition, transfered of sentenced person. MLA, joint investigations, transfer of criminal proceedings, special investigative techniques. We only mentioned three.

However, states rarely use the UNTOC's legal framework to address TOC in the fishery sector. In fact, MLA in criminal matters is one of the frameworks that can

87 The Supreme Court Judge, Surya Jaya opined that the fishery court has not been effective. See Siti Nur Azzura, Not Having All Cases Completed, The Existence of the Fisheries Court is Requested to be Reviewed, merdeka.com, Dec. 11, 2017 available at https://www.merdeka.com/uang/tak-selesaikan-semua-kasus-keberadaan-pengadilan-perikanandiminta-dikaji-ulang.html (last visited on Sept. 3, 2018).

88 CCPCJ, supra note 75.

89 SAntosa, supra note 35.

90 UNTOC arts. 12, 13, 14, 16, 18 \& 27.

91 Id. arts. 16-21. 
be applied to address TOC in the fishery sector. The innovative legal framework to address TOC in the fishery sector at the international level is needed because the crimes are transnational involving two or more States.

MLA is defined as the process of international cooperation to seek and provide assistance in collecting evidence for criminal cases and investigations, in tracking, freezing, confiscating and finally confiscating property derived from the criminal acts process. $^{92}$ MLA may be requested for any of the following purposes: (a) Taking evidence or statements from persons; (b) Effecting service of judicial documents; (c) Executing searches and seizures and conducting freezing; (d) Examining objects and sites; (e) Providing information, evidentiary items and expert evaluations; (f) Providing originals or certified copies of relevant documents and records, including government, bank, financial, corporate or business records; (g) Identifying or tracing proceeds of crime, property, instrumentalities or other things for evidentiary purposes; (h) Facilitating the voluntary appearance of persons in the requesting state party; and (i) Any other type of assistance that is not contrary to the domestic law. ${ }^{93}$

MLA has more benefits than extradition efforts, as it can be done based on agreement or by the reciprocity principle. It not only strives to enforce jurisdiction perpetrators of crimes, but also strengthens the efforts to eradicate, prevent and punish perpetrators of crimes based on their cooperation with other states. ${ }^{94}$

The legal basis of MLA in Indonesia is regulated in Law No 1 of 2006. The Indonesian government has some MLA treaties between Brunei Darussalam, Cambodia, Laos, Malaysia, Filipina, Singapura, Vietnam, Australia, China, Korea, and the US.

\section{Conclusion}

Following the legal certainty principle, the "crime in fisheries" sector is an appropriate legal concept to address IUUF and related crimes. It refers to all criminals involved in the fishery sector and is not considered as a new crime, as these types of crimes have existed before and have been regulated in international and domestic law. The

92 UNODC, Manual on Mutual Legal Assistance and Extradition (2012), available at file:///C:/Users/user/AppData/ Local/Microsoft/Windows/INetCache/IE/4HUAGB07/Mutual_Legal_Assistance_Ebook_E.pdf(last visited on Oct. 30, 2018).

93 UNTOC art 18(3).

94 K. Prost, Breaking Down the Barriers: International Cooperation in Combating Transnational Crime, available at https://www.oas.org/juridico/mla/en/can/en_can_prost.en.html (last visited on Oct. 3 2018). 
novelty lies on the fact that they are perpetrated in the fisheries sector. In addition, it has a legal basis in the Jakarta Concord 2017. At the national level, the Indonesian government needs to overcome TOC in the fisheries sector by amending several articles in the fisheries law, such as: (1) provisions of the 'fisheries crimes' in the Fisheries Act dividing it into two categories, namely 'fisheries crime' and 'crime in fishery crimes"; (2) provisions on the formulation of sanctions that can be divided into sanction not regulating the minimum punishment for fisheries offenders on a small scale, and the formulation of sanctions by including a minimum sentence of four years or more for organised 'fisheries crime'; (3) provision of the fisheries court to deal with crime in the fisheries sector; and (4) formulation of the articles to regulate corporate responsibility clearly.

At the international level, the Indonesian government has campaigned the illegal fishing as TOC and fisheries crime as TOC, but, to date, this has not been fully recognised. Indonesia needs a new strategy to get recognition from the international community by using the appropriate legal terminology, namely crimes in the fishery sector and encouraging other countries to operate MLA to address TOC in the fishery sector. 